\title{
Study of the Potential Anaerobic Co-digestion for Biogas Production from Salvinia molesta and Rice Straw
}

\section{Iqbal Syaichurrozi ${ }^{\varpi}$}

\section{DOI 10.15294/jbat.v6i1.9017}

Department of Chemical Engineering, University of Sultan Ageng Tirtayasa, J1. Jenderal Sudirman Km. 03, Cilegon, Banten Province

\begin{tabular}{l} 
Article Info \\
\hline Article history: \\
Accepted \\
Maret 2017 \\
Approved \\
April 2017 \\
Published \\
June 2017 \\
\hline Keywords : \\
Biogas \\
Rice straw \\
Salvinia molesta \\
Co-digestion \\
\hline
\end{tabular}

\begin{abstract}
The purpose of this research was to analyze the biogas production from co-digestion of Salvinia molesta and rice straw. Ratio of Salvinia molesta and rice straw was 5:0, 4:1, 3:2. Labscale-batch digesters $(600 \mathrm{~mL})$ were operated at room temperature $\left(30^{\circ} \mathrm{C}\right)$ and pressure of 1 atm. Total basis of Salvinia molesta and rice straw was $10 \mathrm{gr}$, water was added with ratio of organic matter:water $=1: 7(\mathrm{w} / \mathrm{w})$, rumen fluid was added as inoculum, initial $\mathrm{pH}$ was adjusted to be 7 . Fermentation process was conducted for 30 days. The results showed that total biogas volume for ratio of $5: 0,4: 1,3: 2$ was $6.30 \pm 0.00 ; 32.76 \pm 18.32 ; 107.54 \pm 18.51$ $\mathrm{mL} / \mathrm{g}$ VS respectively. The $\mathrm{pH}$ of substrate was changing from 7.00 to $6.77 \pm 0.19 ; 6.60 \pm 0.14$; $6.73 \pm 0.09$ for all variables respectively.
\end{abstract}

\section{INTRODUCTION}

Salvinia molesta (SM) is one of weeds which is not expected by every farmer in Indonesia. It has very fast growth rates and biomass cultivation. Thus, it can cover the water surface in a relatively short time (Figure 1). It will reduces the efficiency of irrigation system and the effectiveness of fertilizer in the rice fields, therefore; the production of rice will decrease or will have low yield. Generally, this problem is experienced by many farmers in Indonesia, especially in Lebak regency, Banten.

Lebak is a regency located in Banten. Most of the society in Lebak work as farmers in the total of 43,097 $\mathrm{Ha}\left(430,970,000 \mathrm{~m}^{2}\right)$ area of paddy fields. Meanwhile, the average area of paddy fields for every family is $2,460 \mathrm{~m}^{2}$. According to Susan (2003), in 1 are $\left(4,047 \mathrm{~m}^{2}\right)$ of water area, there are 36 tons of SM. It can be concluded that the total of $\mathrm{SM}$ which can be produced from all paddy fields in
Lebak are $3,833,684.21$ tons with 21.88 tons produced by every family. Based on Soerjani et al. (1987) the growth phase of SM occurred in 3 weeks, thus; in 3 weeks there will be 21.88 tons of SM produced per paddy fields from each family. Therefore, in a year there will be a production of 350.08 tons per area of paddy fields from each family. This is surely a huge number of production.

SM has high concentration of carbohydrate. It is potential to be used as the material of biogas. The comparison between carbohydrate and protein in SM is 11.8446 (Table 1). Biogas is the production of organic materials fermentation by anaerobic bacteria (Hambali et al., 2007). The main components of biogas is methane (50-75 \%volume) and carbon dioxide (25$48 \%$ volume) and other gases in small portion (Juanga et al., 2007; Karellas, 2010).

Many researchers have proven that codigestion will produce more biogas than mono-

\footnotetext{
$\bowtie$ Corresponding author:

Jurusan Teknik Kimia, Universitas Sultan Ageng Tirtayasa,

J1. Jendral Sudirman KM. 03, Cilegon, Provinsi Banten

E-mail: iqbalsyaichurrozi@gmail.com
}

(C) 2017 Semarang State University 

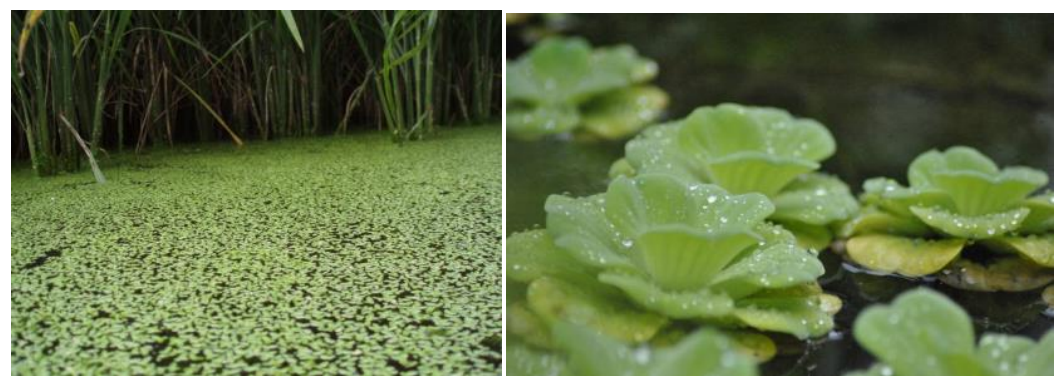

Figure 1. The Growth of SM on the Paddy fields

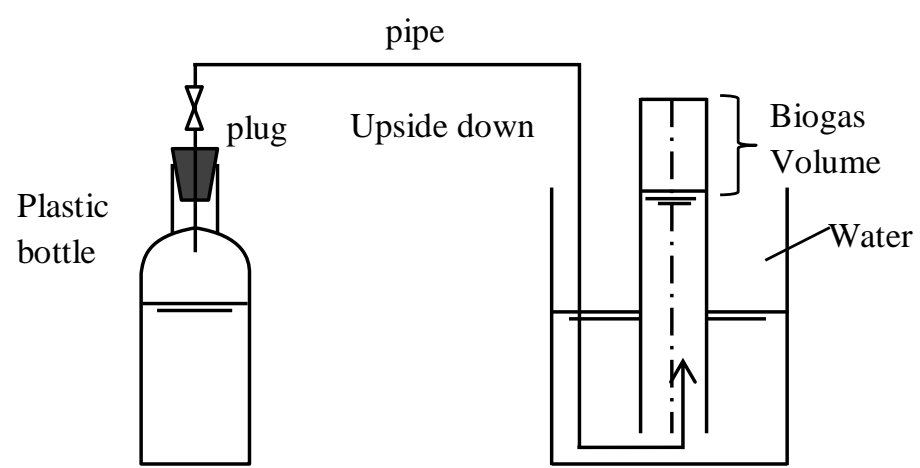

Figure 2 The experimental setup of laboratory scaledigester

digestion. O-Thong et al. (2012) reported that codigestion of oil palm from empty fruit bunches (EFB) and palm oil mill effluent (POME) with the volume ratios of $0.4: 1 ; 0.8: 1$ and $2.3: 1$ produce 25 $32 \%$ which has higher methane production from mono-digestion of EFB. Zhen et al. (2015) also reported that the addition of Egeriadensa (E.d.) to the waste activated sludge (WAS) will increase the production of methane.

Many researchers only review the biogas production from SM (Mathew et al., 2014; Abbasi\&Nipaney; 1984). Mathew et al. (2014) produced biogas from SM with cow rumen as the inoculum (with ratios of cow rumen:SM $=2: 1$ basedon volatile solids). While $\mathrm{pH}$ of the reaction is not controlled. Anaerobic digester was operated at the temperature of $37 \pm 2{ }^{\circ} \mathrm{C}$ in batch reactor. The produced biogas is about $221 \mathrm{~L} / \mathrm{kg}$ VS. Abbasi\&Nipaney (1984) produced biogas using commercial digester operated for 40 days at room temperature. Water was added into the digester with the ratio of 1:7 (w/w). Meanwhile, $\mathrm{pH}$ feed was managed at $6 \pm 0,2$. The produced biogas was 6 $\mathrm{L} / \mathrm{kg}$.

One of the potential farming wastes as the mixture of SM is wasted rice straw. Rice straw has lower ratio of carbohydrate/protein than SM (Table 1). Straw is a rice which grain has been taken, thereby the stem and leaves are the biggest wastes of farming. The production of rice straw in each hectare of paddy fields can be around 12-15 tons of dried material for every harvest, depend on the location and plants varieties. This waste has not been used optimally. This research is aimed to improve the rates of biogas production from SM and rice straw using batch digester with laboratory scales. This research has never been done by other researchers.

\section{RESEARCH METHODOLOGY}

\section{Substrate and Inoculum}

The substrates used in this research were rice straw and SM weed whch were obtained from paddy fields in Lebak-Banten. The composition of straw and SM was analyzed through Van Soest and Proximate analysis in the Laboratory of Nutrition and Consumption Science, Farming Department, Universitas Diponegoro. The compositions of straw and SM are shown in Table 1. Cow rumen fluid was used as the inoculum in this research. This rumen fluid is still fresh and obtained from the slaughterhouse $(\mathrm{RPH})$ in Serang, Banten, Indonesia.

\section{Experimental Setup}

Digester used in this research was batch system digester. Batch digester was used to study the potential of substrate to be a biogas and the influence of the variable towards biogas production 
Table 1. The compositions of SM and wasted straw

\begin{tabular}{lcc}
\hline \multirow{2}{*}{ Components } & \multicolumn{2}{c}{ Substrate } \\
\cline { 2 - 3 } & SM & Rice Straw \\
\hline Water (\% material) & 13,0234 & 5,52310 \\
Total Solid (TS) (\% material) & 86,9766 & 94,4769 \\
Volatile Solid (VS) (\% TS) & 58,4201 & 78,0367 \\
Raw Fiber (\% TS) & 25,4020 & 37,9998 \\
Raw Carbohydrates (\% TS) & 41,8624 & 63,3273 \\
Raw Protein (\% TS) & 3,53430 & 9,18630 \\
Raw Fats (\% TS) & 0,93050 & 0,92420 \\
Lignin (\% Raw Fiber) & 53,1108 & 21,4930 \\
Hemicellulose (\% Raw Fiber) & 12,5733 & 17,0892 \\
Cellulose (\% Raw Fiber) & 8,28150 & 25,0626 \\
Carbohydrate/Protein = C/N & 11,8446 & 6,89370 \\
\hline
\end{tabular}

Table 2. Substrate variations

\begin{tabular}{llllll}
\hline Run & Salvinia:Straw & Salvinia $(\mathrm{gr})$ & Straw $(\mathrm{gr})$ & Rumen $(\mathrm{mL})$ & $\mathrm{C} / \mathrm{N}$ \\
\hline 1 & $5: 0$ & 10 & 0 & 25 & 11,84 \\
2 & $4: 1$ & 8 & 2 & 25 & 9,89 \\
3 & $3: 2$ & 6 & 4 & 25 & 8,70 \\
\hline
\end{tabular}

Notes: $\mathrm{C} / \mathrm{N}=$ Carbohydrate/Protein

in laboratory scale (Syaichurrozi et al., 2016a). A digester in the form of plastic bottle with volume of $600 \mathrm{~mL}$ used in the laboratory scale research. Beside digester, the tool used in this research were rubber stoppers, hose, clamp, $\mathrm{pH}$ meter, and measuring cup. In details, anaerobic digester in laboratory scale can be seen in Figure 2.

\section{Experimental Design}

This research focuses on the review of codigestion towards biogas production compared to mono-digestion process. SM and straw was cut into a small size and then heated under the temperature of $60{ }^{\circ} \mathrm{C}$. Then, it was mashed to the size of 18 mesh. SM and rice straw with the total basis of 10 gram was added into the digester. Water was then added with the ratio of $1: 7 \mathrm{w} / \mathrm{w}$. Substrate $\mathrm{pH}$ was adjusted to be 7.0 using $2 \mathrm{M} \mathrm{HCl}$ and $2 \mathrm{M} \mathrm{NaOH}$. $25 \mathrm{~mL}$ of rumen fluid was added as the provider of methane bacteria. The ratios of SM and straw were 5:0, 4:1, 3:2 in mass basis. The difference of SM and straw composition in the mixture of substrate cause ratio differences of carbohydrate/protein. Carbohydrate is the source of carbon (C), and protein is the source of nitrogen $(\mathrm{N})$. Thereby, in this research, the ratios carbohydrate/protein is assigned by $\mathrm{C} / \mathrm{N}$. The variables in this research can be seen in Table 2. All variations were done in duplo.

\section{Experimental Procedures}

The produced biogas was measured every two days to see the biogas production each day. Substrate $\mathrm{pH}$ during the fermentation was also measured using $\mathrm{pH}$ meter to record the $\mathrm{pH}$ profile. The formed ammonium was measured in the $0^{\text {th }}$, $10^{\text {th }}, 20^{\text {th }}$, and $30^{\text {th }}$ day of research. In these days, few samples were taken (some $\mathrm{mL}$ ). After that, the samples were analyzed in the Testing Laboratory of Farming Industry Department in IPB. The production of ammonia was measured using the equation (1) by El-Mashad et al. (2004) and volatile fatty acids (VFAs) was measured using equation (2) suggested by Paul and Beauchamp (1989).

$$
\begin{aligned}
& \mathrm{NH}_{3}-\mathrm{N}=\left(\mathrm{NH}_{4}^{+}-\mathrm{N}\right)\left[1+\frac{10^{-p H}}{10^{-\left(0.1075+\frac{2725}{\mathrm{~T}}\right)}}\right]^{-1} \\
& p H=9.43-2.02(\mathrm{VFAs}) /\left(\mathrm{NH}_{4}^{+}-\mathrm{N}+\mathrm{NH}_{3}-\mathrm{N}\right)
\end{aligned}
$$

Where,

$\mathrm{NH}_{3}-\mathrm{N}$ : Ammonia (mg/L)

$\mathrm{NH}_{4}{ }^{+}-\mathrm{N}$ : Ammonium (mg/L)

$\mathrm{pH} \quad$ : Substrate acidity condition

$\mathrm{T} \quad$ : Temperature (K), in the range of $273-373$

$\mathrm{K}$

VFAs : Volatile Fatty Acids (mg/L) 


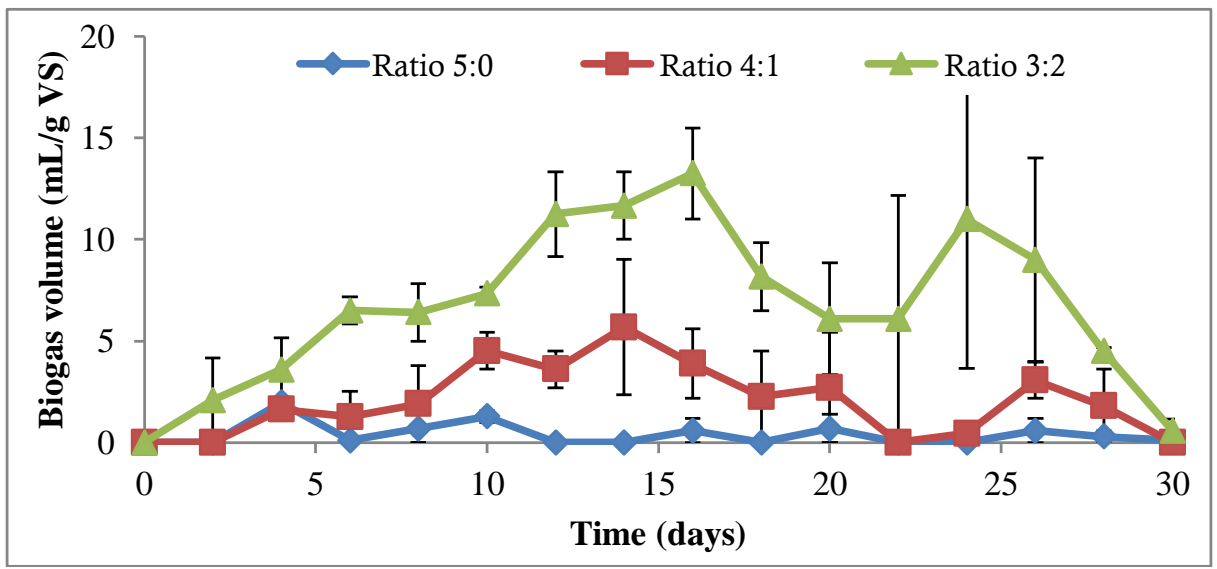

(a)

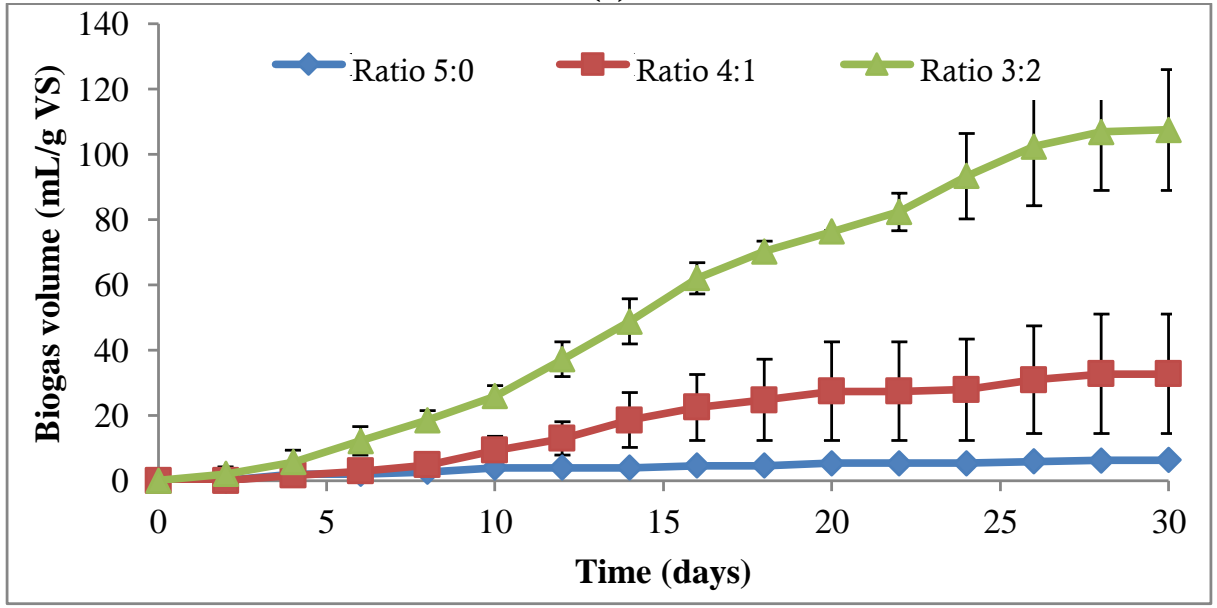

(b)

Figure 2. The production of biogas volume (a) daily, (b) cumulative

\section{RESULTS AND DISCUSSIONS}

\section{Biogas Production}

The profile of daily and cumulative biogas production are served in Figure 2. The results of the measurement show that the more rice straw in the substrate, the more biogas produced. It is because SM has more lignin composition rather than in rice straw (Table 1). Lignin is very difficult to degrade by microbes, so, the biogas production rates is getting slower. Substrate order which have lignin are 5:0 $>4: 1>3: 2$. The produced total volume of biogas after 30 days of fermentation with substrateof $5: 0 ; \quad 4: 1 ; \quad 3: 2$ were $6.30 \pm 0.00$; $32.76 \pm 18.32 ; 107.54 \pm 18.51 \mathrm{~mL} / \mathrm{g}$ VS (Figure 2(b)).

Figure 2(a) shows that the highest daily biogas productions in 5:0, 4:1, 3:2 were $1.97 \pm 0.00$; $5.69 \pm 3.34 ; 13.25 \pm 2.25 \mathrm{~mL} / \mathrm{g}$ VS in the $4^{\text {th }}, 14^{\text {th }}$, and $16^{\text {th }}$ day respectively. It shows that $3: 2$ ratio is easier to degrade since it contains the smallest lignin than the other variables. It is shown by the constant increase of daily biogas production until the $16^{\text {th }}$ day. Meanwhile, variable of 5:0 (SM alone) containing the highest lignin in the $4^{\text {th }}$ day of biogas production. Then, it continuously decreased until the end of fermentation.

Beside lignin in the substrate, the comparison between carbohydrate/protein is an important factor. Carbohydrate represents the total of carbon (C), and protein represents the total of nitrogen $(\mathrm{N})$. Thus, the comparison between carbohydrate/protein $=\mathrm{C} / \mathrm{N}$. Syaichurrozi et al. (2013) reported that the process of carbohydrate digestion involves acid bacteria which produce acetic acid, hydrogen, carbon dioxide and VFAs (propionate acid and butyrate acid). In the other side, protein in the substrate will experience decomposition to become ammonia/ammonium. Ammonia $\left(\mathrm{NH}_{3}\right)$ /ammonium $\left(\mathrm{NH}_{4}{ }^{+}\right)$can be used by bacteria as the source of nitrogen (Sung \& Liu, 2003). Nonetheless, ammonia and ammonium will be a poison to certain amount of bacteria. From Table 1 , ratio of $5: 0,4: 1,3: 2$ have $C / N$ ratios of $11.84 ; 9.89 ; 8.70$. Syaichurrozi et al. (2016) also 


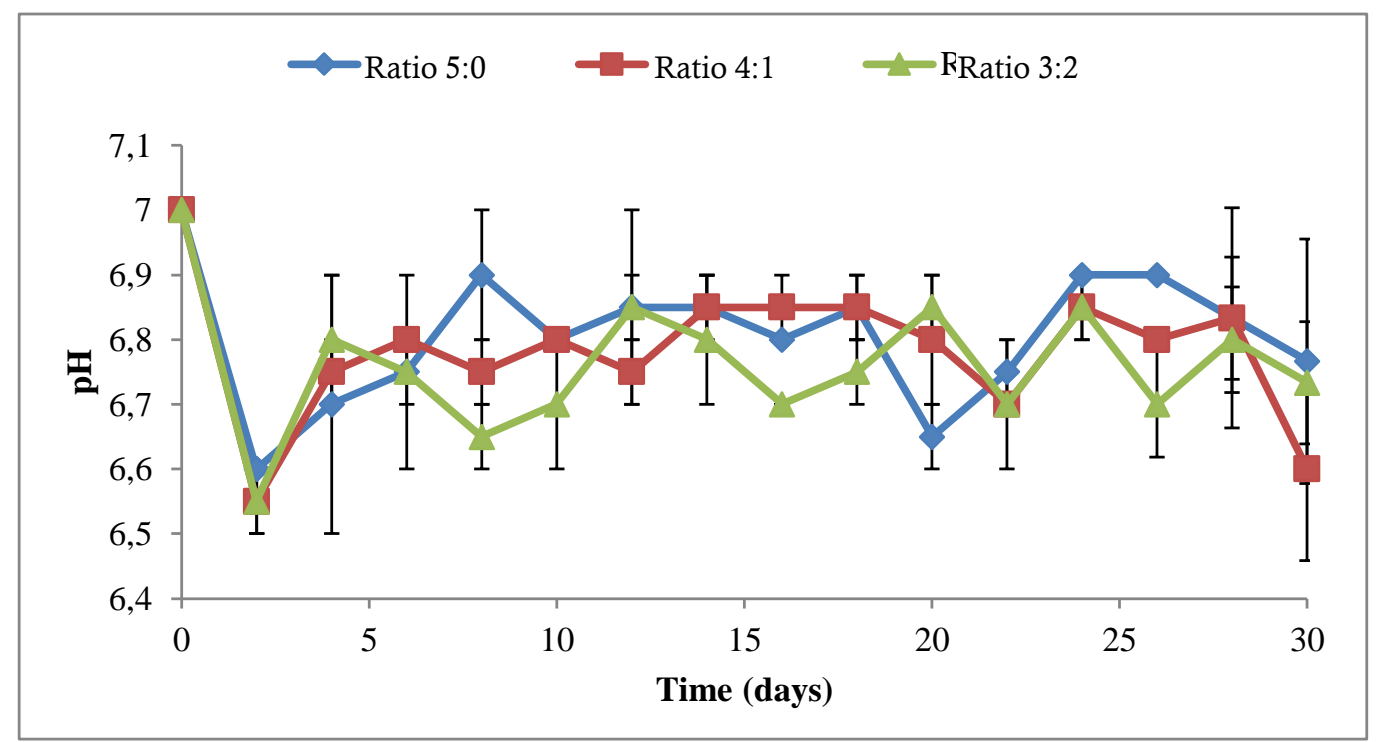

Figure 3. Substrate $\mathrm{pH}$ profile during the fermentation process

reported that substrate with correct $\mathrm{C} / \mathrm{N}$ comparison will produce maximum biogas. The result will show that $\mathrm{C} / \mathrm{N}=8.70$ produce more biogas than 11.84 and 9.89 .

\section{pH Profile}

$\mathrm{pH}$ profile of substrate during biogas production is projected in Figure 3. $\mathrm{pH}$ substrate experienced less decrease in the beginning of cultivation, then experienced dip until the end of cultivation. According to Elbeshbishy \& Nakhla (2012), the decrease of $\mathrm{pH}$ is caused by bunch of VFAs production in the beginning of fermentation process, then $\mathrm{pH}$ would experience gradual raise caused by the formation of $\mathrm{NH}_{4}-\mathrm{N}$ during protein degradation. Ammonia $\left(\mathrm{NH}_{3}-\mathrm{N}\right)$ can react to water, then form ammonium bicarbonate $\left(\mathrm{NH}_{4} \mathrm{~N}\right)$, a natual $\mathrm{pH}$ buffer. In this research, $\mathrm{pH}$ substrate did not experience significant changes. $\mathrm{pH}$ substrate was 7 in the beginning of fermentation. In contract, it was $6.77 \pm 0.19 ; 6.60 \pm 0.14 ; 6.73 \pm 0.09$ in every variation 5:0, 4:1, 3:2 in the end. It shows that the production of VFAs and ammonium/ammonia was in a relatively balance amount.

\section{Production of Ammonium, Ammonia and VFAs}

During the fermentation process, carbohydrate will be converted to be VFAs and protein become ammonium/ammonia. The very high concentration of VFAs will obstruct the activity of methane bacteria. The allowed maximum concentration of VFAs is $2000 \mathrm{mg} / \mathrm{L}$. It is aimed to make the fermentation works normally
(Yadvika et al., 2004). Meanwhile, the concentration of ammonia $80 \mathrm{mg} / \mathrm{L}$ is inhibiting the growth and $150 \mathrm{mg} / \mathrm{L}$ concentration it will be a poison to bacteria. Ammonia will be an ammonium ion in the substrate depend on $\mathrm{pH}$ condition. Ammonium is not dangerous except in a very high concentration. $1500-10000 \mathrm{mg} / \mathrm{L}$ concentration of ammonium started to disturb the growth of bacteria and 30000 $\mathrm{mg} / \mathrm{L}$ is poisonous to bacteria (Deublein \& Steinhauser, 2008).

In Figure 4, the concentration of ammonium in the end of the fermentation for variables $5: 0,4: 1,3: 2$ were 134,$55 ; 36,68 ; 317,70$ $\mathrm{mg} / \mathrm{L}$. Meanwhile, the concentration of ammonia in the end of the fermentation in each variable were 0,$63 ; 0,12 ; 1,35 \mathrm{mg} / \mathrm{L}$. The concentration of VFAs in the end of the fermentation were $178.00 ; 51.54$; $426.45 \mathrm{mg} / \mathrm{L}$ for each variable. It showed that the concentration of ammonium, ammonia and VFAs were under the maximum limit (Figure 4). Bacteria need VFAs as an intermediate product in methane production. Ammonium and ammonia are needed by bacteria as the source of carbon. It can be concluded that the higher the concentration of VFAs in the expected range, the produced biogas will be higher. Similarly, the higher the concentration of ammonium/ammonia in certain ranges, the biogas will be higher.

Based on Figure 2, ratio 4:1 produced more biogas than ratio 5:0, but; the production of ammonium, ammonia and VFAs is less than 5:0 (Figure 4). It is because in ratio $4: 1$ these compounds are used by bacteria to produce biogas. 


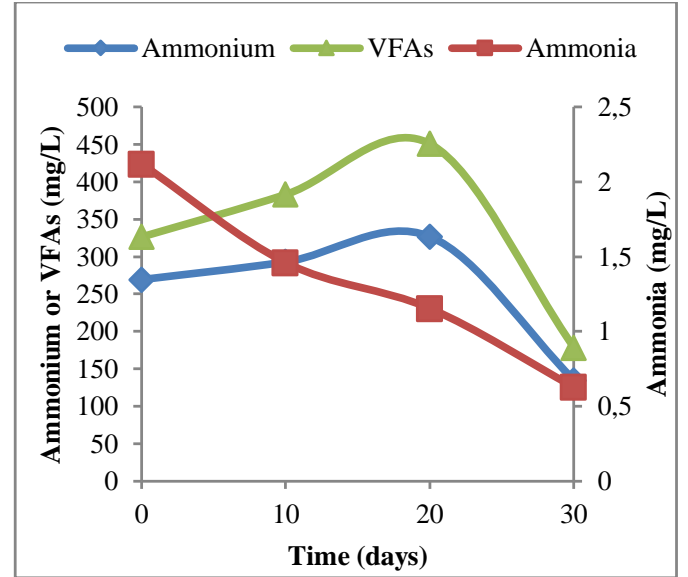

(a)

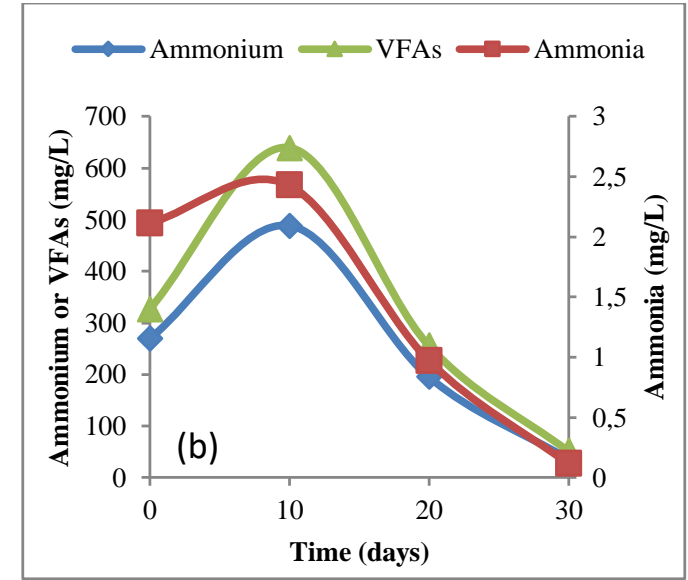

(b)

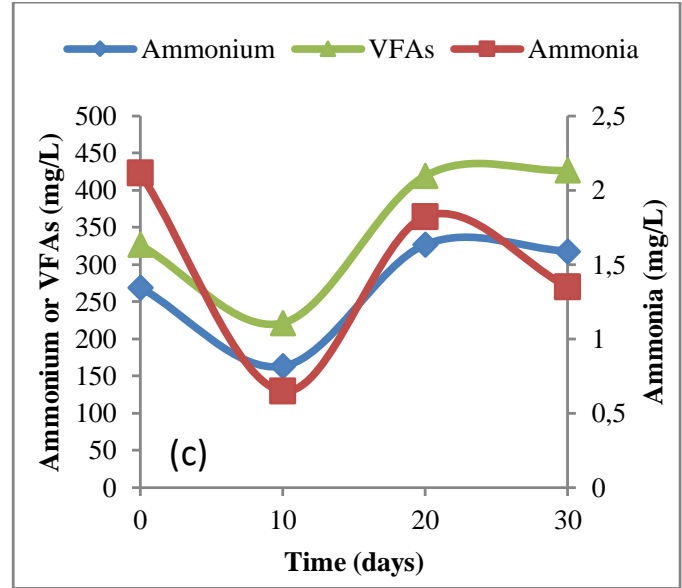

(c)

Figure 4. The production of Ammonium, Ammonia and VFAs during the fermentation process in substrate ratio of (a) 5:0, (b) $4: 1$, (c) $3: 2$

Meanwhile, in ratio 5:0, many of these compounds are not used by bacteria, so, the concentration was still high. In ratio 3:2, the production of VFAs, ammonium, and ammonia were the most among all variation (Figure 4). These compounds are continuously produced until the end of fermentation. Biogas was also continuously produced until the end of fermentation. It shows that bacteria grows well in substrate of 3:2.

\section{CONCLUSION}

The fermentation was done for 30 days. The substrates in this research consist of mixtures from SM and rice straw with ratio of 5:0, 4:1, 3:2. They were utilized as biogas material. This research shows that the total volume of biogas in ratio of 5:0, $4: 1, \quad 3: 2$ were $6.30 \pm 0.00 ; \quad 32.76 \pm 18.32$; $107.54 \pm 18.51 \mathrm{~mL} / \mathrm{g}$ VS. The condition of substrate $\mathrm{pH}$ changes from 7.00 to be $6.77 \pm 0.19 ; 6.60 \pm 0.14$; $6.73 \pm 0.09$ in every variation $5: 0,4: 1,3: 2$. The production of ammonium, ammonia and VFAs was observed in every 10 days.

\section{ACKNOWLEDGEMENTS}

The researcher wants to say thanks to Waste Management Laboratory, Chemical Engineering Department, University of Sultan Ageng Tirtayasa for providing laboratry facility. The researcher also would like to thank the students, Suhirman and Topik Hidayat, for helping in taking data in the laboratory.

\section{REFERENCES}

Abbasi, S.A., Nipaney, P.C. 1984. Generation of biogas from Salvinia molesta (Mitchell) on a commercial biogas digester. Environmental Technology Letters. 5(1-11) : 75-80

Deublein, D., Steinhauser, A. 2008. Biogas from Waste and Renewable Resources. Weinheim: Wiley-VCH Verlag. 
El-Mashad, H.M., Zeeman, G., van Loon, W.K.P., Bot, G.P.A., Lettinga, G. 2004. Effect of temperature and temperature fluctuation onthermophilic anaerobic digestion of cattle manure. Bioresource Technology. 95 : 191-201.

Elbeshbishy, E., Nakhla, G. 2012. Batch anaerobic co-digestion of proteins and carbohydrates. Bioresource Technology. 116 : 170-178.

Hambali, E., Musdalipah, S., Halomoan, A.T., Pattiwiri, A.W., Hendroko, R. 2007. Teknologi Bioenergi, Jakarta: Agromedia.

Juanga, J.P., Visvanathan, C., Tränkler, J. 2007. Optimization of Anaerobic Digestion of Municipal Solid Waste in Combined Process and Sequential Staging. Journal of Waste Management Resources. 25 : 30-38.

Karellas, S.B. 2010. Development of an investment decision tool for biogas production from agricultural waste. Jurnal Renewable and Sustainable Energy Reviews. 14 : 12731282.

Mathew, A.K., Bhui, I., Banerjee, S.N., Goswani, R., Chakraborty, A.K., Shome, A., Balachandran, S., Chaudhury, S. 2014. Biogas Production from Locally Available Aquatic Weeds of Santiniketan through Anaerobic Digestion. Clean Technology Environmental Policy.

O-Thong, S. Boe, K., Angelidaki, I. 2012. Thermophilic anaerobic co-digestion of oil palm empty fruit bunches with palm oil mill effluent for efficient biogas production. Applied Energy. 93 : 648-654.

Paul, J. W., Beauchamp, E.G. 1989. Relationship between Volatile Fatty Acids, Total Ammonia, and $\mathrm{pH}$ in Manure Slurries. Biological Wastes. 29 : 313-318.

Soerjani, M., Koestermans, A.J.G.H., Tjitrosoepomo, G. 1987. Weed of Rice in Indonesia. Balai Pustaka, Jakarta.
Sung, S., Liu, T. 2003. Ammonia inhibition on thermophilic anaerobic digestion. Chemosphere. 53(1) : 43-52.

Susan, S. 2003. Water Quality Education Specialist. University of Nevada Cooperative ektention. Nevada Department of Agriculture.

Syaichurrozi, I., Budiyono, Sumardiono, S. 2013. Predicting kinetic model of biogas production and biodegradability organic materials: Biogas production from vinasse at variation of $\mathrm{COD} / \mathrm{N}$ ratio. Bioresource Technology. 149 : 390-397.

Syaichurrozi, I., Rusdi, R., Hidayat, T. Bustomi, A. 2016a. Kinetics Studies Impact of Initial $\mathrm{pH}$ and Addition of Yeast Saccharomyces cerevisiae on Biogas Production from Tofu Wastewater in Indonesia. IJE TRANSACTIONS B: Applications. 29(8) : 1037-1046.

Syaichurrozi, I., Rusdi, Dwicahyanto, S., Toron, Y.S. 2016b. Biogas Production from CoDigestion Vinasse Waste and TofuProcessing Wastewater and Kinetics. International Journal of Renewable Energy Research. 6(3) : 1057-1070.

Yadvika, S., Sreekrishnan, T.R., Kohli, S., Ratna V. 2004. Enhancement of biogas production from solid substrates using different techniques- a review. Bioresource Technology. $95: 1-10$.

Zhen, G., Lu, X., Kobayashi, T., Li, Y.-Y., Xu, K., Zhao, Y. 2015. Mesophilic anaerobic codigestion of waste activated sludge and Egeria densa: Performance assessment and kinetic analysis. Applied Energy. 148 : 7886. 